\title{
MicroRNA 509-5p
}

National Cancer Institute

\section{Source}

National Cancer Institute. MicroRNA 509-5p. NCI Thesaurus. Code C142769.

A 21 ribonucleotide sequence that is a final product of the processing of either MIR509-1 pre-miRNA or MIR509-2 pre-miRNA. This oligonucleotide may be involved in the negative regulation of gene expression. 